\title{
Reclaiming the New, Remaking the Local: Shenzhen
} at 40

Mary Ann O'Donnell and Jonathan Bach

\section{(2) OpenEdition \\ Journals}

Electronic version

URL: https://journals.openedition.org/chinaperspectives/11848

DOI: 10.4000/chinaperspectives. 11848

ISSN: 1996-4617

\section{Publisher}

Centre d'étude français sur la Chine contemporaine

\section{Printed version}

Date of publication: 1 June 2021

Number of pages: $71-75$

ISSN: 2070-3449

\section{Electronic reference}

Mary Ann O'Donnell and Jonathan Bach, "Reclaiming the New, Remaking the Local: Shenzhen at 40", China Perspectives [Online], 2021/2 | 2021, Online since 01 June 2021, connection on 18 November 2022. URL: http://journals.openedition.org/chinaperspectives/11848; DOI: https://doi.org/10.4000/ chinaperspectives. 11848 


\title{
Reclaiming the New, Remaking the Local: Shenzhen at 40
}

\author{
MARY ANN O'DONNELL AND JONATHAN BACH
}

KEYWORDS: Shenzhen, cultural geography, rural urbanisation, local identity, reclamation, urban villages, Bao'an.

"Without the Party, New China would not exist."1 - song and lyrics by Cao Huoxing (曹火星), 1943.

The spectre of the new haunts China. The ideological force of the new is such that Shenzhen is celebrated for being both a place where innovation happens, and a city that is able to constantly renew itself. During his speech celebrating the $40^{\text {th }}$ anniversary of the Shenzhen Special Economic Zone (SEZ), for example, CCP General Secretary Xi Jinping affirmed Reform and Opening Up, the Guangdong Hong Kong Macao Greater Bay Area (GBA), and innovation and technology as key features of contemporary national strategy. Xi especially pointed to Shenzhen as a place where ideas are quickly generated, prototyped, and turned into products and services. Moreover, Xi called Shenzhen the GBA's engine, offering the city's experience as a model for urban renewal and regional restructuring.

In this paper, we take the SEZ's $40^{\text {th }}$ anniversary as an opportunity to reflect on how Shenzhen became new, is constantly renewed, and maintains its aura of being new. We argue that Shenzhen has achieved "new" status by re-claiming what was decidedly not new - the long history of indigenous villages and regional localities. More recently the city has also begun renewing older neighbourhoods that were formerly "new." We contend that urban renewal in Shenzhen is a process by which one form of the local, bendi (本地), understood as an indigenous category, is transformed into a form of locality, difang (地方), understood as a category of national governance. This transformation, we suggest, can be understood as reclamation; just as land is reclaimed from the city's coastal waters, the new is reclaimed from obsolete cultural geographies. This process is cyclical: in Shenzhen, as buildings, villages, and neighbourhoods age into obsolescence they also become indigenised, justifying the next era of urban renewal. The process suggests a historical shift in the relation between state-making and local identities, as the practice of fixing bodies in place gives way to affixing categories of belonging to ever more mobile bodies. We hope that tracking this process of obsolescence and reclamation with respect to discourses of the new will not only help scholars of China understand how Bao'an County, the historical site of today's Shenzhen, was reconstituted within and against the Shenzhen municipal apparatus, but how cities more generally create, deploy, and transform the new.

\section{Historic forms of the local and locality in Bao'an}

In contemporary Chinese, the local as a historical category, bendi (本 地), referring to local society and signalling an intimacy of belonging, can be contrasted with the local as a category of national governance, difang (地方), which locates specific governance structures in relation to the central government, or zhongyang (中央). ${ }^{2}$ We render difang here as "state-defined locality," in contrast to the indigenous local (bendi). This is a subtle, but profound difference: bendi not only includes historical rights and territorial identities sutured by specific places, but also emotional commitments to those places. Difang absorbs these rights and identities into the larger structure of the state apparatus to deploy them toward non-local ends.

The current distinction between the local and the state-defined locality was introduced in Bao'an County as inhabitants received urban and rural hukou (戶口), respectively, redefining their place in national production by physical location. ${ }^{3}$ This caused a disjuncture for Bao'an residents, who continued to identify with traditional local geographies while acquiring places in the state apparatus as part of the new Mao-era locality. ${ }^{4}$ When Bao'an County was elevated to Shenzhen City in 1979, state-defined locality became the mediating category with respect to the central government. This set off a series of restructurings that would continue over the next three decades: The central government elevated Shenzhen City to the status of SEZ in 1980, dividing it into the SEZ and New Bao'an County two years later. The SEZ was understood as an explicit extension of national policy, while New Bao'an was identified with local interests. This spatialised distinction between the SEZ as locality and New Bao'an as local was formalised in 1982 by a physical border between the two areas - the so-called "second line" (erxian 二線), which ran parallel to the Shenzhen-Hong Kong border. Shenzhen City thus comprised the SEZ, a $327.5 \mathrm{~km}^{2}$ long strip of territory between the border and the second line,

\footnotetext{
1. The famous lyrics are “沒有共產黨就沒有新中國” (Meiyou gongchandang jiu meiyou xin Zhongguo).

2. Bendi people are defined in opposition to those who are outsiders, or waidi (外地) people. Both zhongyang and difang are peopled by bureaucrats, who may or may not have bendi ties.

3. Hukou refers to the 1958 household registration system that separated urban and rural populations.

4. On transvalued identities, see Anagnost (1997).
} 
and New Bao'an County outside the second line. Circa 2003, Shenzhen loosened restrictions on movement into the SEZ, and the second line was officially decommissioned in $2010 .^{5}$

Although the SEZ and New Bao'an County were the scaffolding within which Shenzhen developed, its emergent locality was shaped by Bao'an's cultural geographical mix of Cantonese and Hakka villages and boat dwellers. ${ }^{6}$ Before the establishment of the hukou system, Cantonese villages in Bao'an were known as "local" (m. bendi c. punti 本地) and located along the Lingding Sea and Shenzhen Bay within the littoral cultural geography of Guangzhou and the Pearl River Delta. ${ }^{7}$ In contrast, Hakka settlements (m. kejia c. hakka 客家) were considered interlopers, entering the area after 1683 , and located in the mountain hinterlands of Guangdong, Fujian, and Jiangxi Provinces, and the Dapeng Peninsula (Figure 1). ${ }^{8}$ The dominant Cantonese settlement and its Weitou subculture centred on the historic county seat at Nantou, while the dominant Hakka mountain settlements extended to coastal subcultures along the Dapeng Peninsula (Figure 2). Boat dwellers, pejoratively known as "egg people" (m. danjia, c. tanka 蛋家), inhabited bays and harbours, trading at punti and Hakka markets.

The hukou system transvalued Bao'an forms of the local, including connections to Hong Kong, especially settlements in the New Territories. Before the establishment of the PRC in 1949, punti villages asserted their connection to regional government, while Hakka and fishing families were considered "guests." Hukou made all Bao'an residents equally part of the locality with respect to Beijing, without, however, effectively eliminating historic hierarchies, cultural forms, and recognised land and water rights. After the establishment of the SEZ, the scale of immigration further blurred the meaning of bendi to include all indigenous settlements, while Shenzhen as locality was slowly being "indigenised" in respect to provincial and national government levels. These levels would come to reclaim what had once been "new" in Shenzhen, placing its inhabitants within the state apparatus via a performative logic of reclaiming.

Figure 1. Location of the Cantonese and Hakka heartland in Guangdong, Fujian, and Jiangxi Provinces.

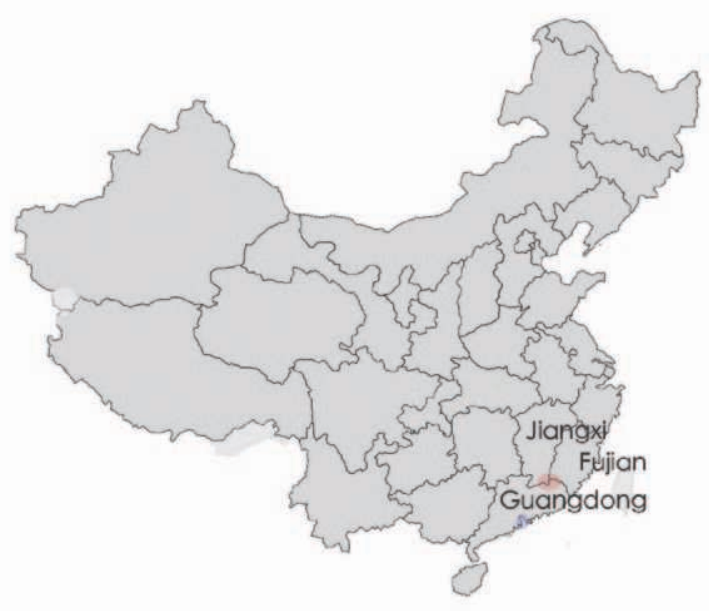

Cantonese heartland Hakka heartland

Source: "Futian New Genealogy" research project, Shenzhen Centre for Design, 2015. Credits: Authors' collection.
Figure 2. Map of Shenzhen's cultural geography.

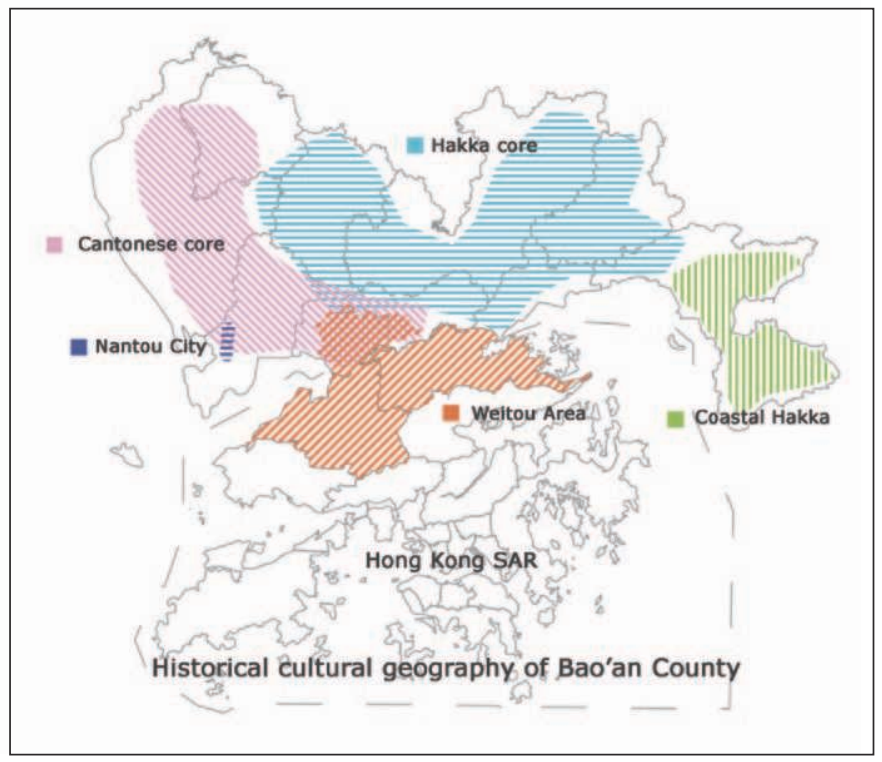

Source: "Futian New Genealogy" research project, Shenzhen Centre for Design, 2015 Credits: Authors' collection.

\section{The performative logic of reclaiming the new}

On 8 July, 1979, China Merchants-Shekou fired "the first shot of Reform and Opening Up, ${ }^{, 10}$ detonating the Sixth Bay in Shekou in order to reclaim a section of coastline and to level hilly land for industrial development. The "first shot" became iconic because it initiated a common means of reclamation in Shenzhen - "moving mountains to fill the sea" (yishan tianhai 移山填海). ${ }^{11}$ The 1980 plan for the Shekou Industrial Zone (Figure 3), for example, suggests the extent to which mountains were moved to replace a sparsely populated network of fishing villages and markets with a densely populated urban settlement. Similarly, during the 1990s, large sections of Antuoshan Mountain in Futian were quarried for both high-grade building stones and low-grade landfill, levelling sections of the mountain range later developed as residential and commercial areas. These large-scale engineering projects not only created the city's tabula rasa by displacing villages and scarce farmland, lychee orchards, rice polders, and fishponds, but also made this tabula rasa the city's new "homeland."

As Bao'an's coastline was straightened and its mountain ranges levelled, the indigenous became identified with the obsolete. In its place, the first iteration of Shenzhen rose - a manufacturing city comprising container ports, industrial parks, and densely populated living areas. The residents of this new landscape were not indigenous to the land, but rather "at home" in the state system and its infrastructures. The expression "Shekou people," for example, referred to those who held Shekou hukou via urban

5. O'Donnell and Wan (2016) place second line governance with respect to management of the Shenzhen Hong Kong border.

6. The boat dwellers had no land rights but would dock in bays and trade with nearby villages

7. Punti villages trace their roots back to the Southern Song, circa 1200 CE. Cantonese and Hakka are both considered indigenous to Shenzhen. We provide Cantonese and Hakka transliterations when referring to local cultural geography and Mandarin pinyin, which became the city's lingua franca during the 1990s, when referring to the locality.

8. The Coastal Eviction Edict was rescinded in 1683

9. On ethnic hierarchies during the Ming and Qing Dynasties in Guangdong, see Faure and Siu (1995).

10. The phrase “改革開放的第一炮" (Gaige kaifang de diyi pao) appeared in the Shekou Museum of China's Reform and Opening Up, and throughout Chinese media.

11. The most common form of land reclamation during the SEZ's first two decades. 
Figure 3. The China Merchants Shekou Industrial Zone General Layout from April 1980, on display at the Shekou Museum of China's reform and opening up.

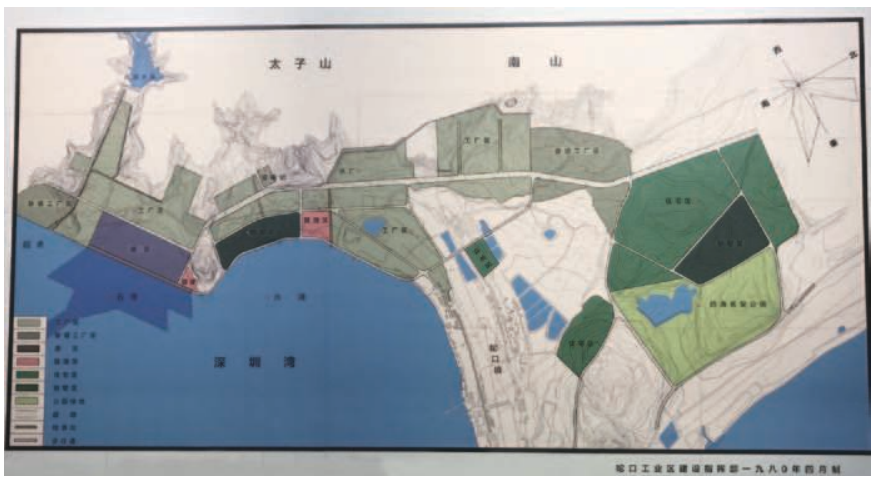

Credits: Photograph taken by the authors.

institutions even if they were born and raised elsewhere. Indigenous lineages, languages, and identities did not completely disappear, but instead became part of the new locality - embodied markers of a world that was becoming obsolete.

This process was repeated throughout the SEZ. In addition to Shekou, the reclamation of Bao'an began at the Shenzhen-Hong Kong border in Luohu-Shangbu. Luohu comprised the historic Shenzhen Market, its eponymous railway station, and neighbouring villages. As the new city was named after Shenzhen Market, the commercial centre of Luohu was renamed Dongmen. Luohu was expanded to include Shangbu, a satellite new town that included a city hall, two industrial parks, and living areas. By 1986 both Shekou and Luohu-Shangbu had already exploded the confines of their initial boundaries, and the "1986 Comprehensive Plan for the Shenzhen SEZ" identified six sites to "fill in" the space between Luohu and Shekou, thereby "reclaiming" the local as a chain of statedefined localities (O'Donnell 2019). These sites, moving from east to west along the border with Hong Kong, were: Shatoujiao, Luohu-Shangbu, and Nantou. Overseas Chinese Town (OCT) was established in the underpopulated hills between Shangbu and Nantou, with Shekou being located at the tip of the Nantou Peninsula. Bao'an's new county seat was established just north of the second line along the Pearl River. At each of these sites the blurred contours of Bao'an's indigenous cultural geography still pulsed beneath the city's relentlessly urbane veneer.

The creation of urban districts out of pre-existing cultural geographies highlights a double transformation that remains critical to how Shenzhen operates: local sites were turned into locality, and with them local people into hukou holders. Indigenous locals now share the same status as immigrants who hold Shenzhen hukou. However, tensions between nominal equality within the locality and practical inequalities with respect to the indigenous local are dialectical, creating the social substrate from which the new can be reclaimed.

Shatoujiao, reclaimed within the context of developing the Yantian section of the port of Shenzhen, illustrates this double transformation. ${ }^{12}$ Historically, Shatoujiao was a Hakka periphery located a full day's walk across Wutongshan Mountain to Shenzhen Market (present-day Dongmen) and a treacherous 24-hour boat trip from Victoria Harbour (Hase 1993). When the Sino-British border was redrawn in 1898, it disadvantaged Shatoujiao Market because coastal villagers and fishermen primarily approached the area by boat rather than on foot. As the coastline was considered British territory up to the high tide mark, anyone arriving by boat was forced to pay customs charges for transferring goods from boats to the market. To avoid charges, villagers moved the market across the Sino-British border. In the early 1980s, Shatoujiao was designated a cross-border site like Luohu-Shangbu and Shekou. However, Shatoujiao remained isolated from core SEZ developments because it lacked the population density and transportation infrastructure to support cross-border trade and manufacturing chains. Instead, the later development of the mouth of Shatoujiao Bay as Yantian Terminal allowed for the new locality to root itself at the edge of the South China Sea. During this transition, Shatoujiao was rebranded via Zhongying Street, which during the 1990s became a tourist site where mainland visitors to the SEZ could purchase Hong Kong and foreign products. In 1998, Luohu District was partitioned into Luohu and Yantian, with the line of division the historic punti-hakka boundary of the Wutongshan Mountain range.

Shatoujiao's experience suggests how the local is subordinated to a higher order locality in three steps. First, the environment is physically reshaped; the mountains that enclosed Shatoujiao were levelled to create land for urban development. Second, the historical cultural geography is redeployed for the purposes of a new historical actor; when the initial effort to transform the area into an industrial centre failed, Shatoujiao became known as a cross border commercial and tourist area that embodied the Shenzhen goals of reform and opening up. Third, the emergent society is administratively restructured; once Yantian Terminal was constructed, Shatoujiao could be reclaimed as a neighbourhood within the new urban centre of Yantian.

\section{From spatialised identities to bureaucratic emplacements}

Shenzhen's division into local sites and localities was never absolute market towns in New Bao'an and villages inside the SEZ formed exceptional pockets on both sides of the second line. However, by 2004, the absorption of residual rural areas into the state apparatus was complete, allowing Shenzhen to proudly announce itself as the first Chinese city with no villages. ${ }^{13}$ Technically, this meant that local Bao'an was now part of Shenzhen locality. What then remained for the city to reclaim as new? It is at this moment that we see the conflation between the new as locality with state forms of power, and the old as the local with in situ urban forms. This expresses itself as a dialectical binary, whose implicit hierarchy allows for the ongoing production of local obsolescence, combined with the compulsion for renewal of what has become obsolete. How did this come to pass?

During the 1980s, Bao'an villages still held traditional rights to their land, setting up businesses alongside, but not within, the new locality. For example, Caiwuwei, located next to Dongmen, built village industrial parks, taking advantage of their access to the port of Hong Kong via the Wenjingdu checkpoint in Luohu. However, beginning in the 1990s, local land was incorporated into the city apparatus as either a neighbourhood

12. The port has terminals in Yantian, Qianhai, and Shekou

13. Absorption of rural areas inside the second line into the urban apparatus took place from 1992 to 1996.

14. Administrative nomenclature reinforces the logic of reclamation: Before 2004, neighbourhoods were the lowest level of urban governance, while villages were the lowest level of rural governance. Once Shenzhen became a city without villages, neighbourhoods and villages were redesigned as communities (shequ 社區), formally equivalent within the locality, but with access to historically different resources in situ. 
(juweihui 居委會) or a village (cun 村), corresponding to the locality or the local, respectively. ${ }^{14}$ Within the city apparatus, Caiwuwei's undeveloped land was expropriated by the government for future stateled development, and villagers were given Shenzhen hukou, making them full citizens in the new city. The village as constituted through the local cultural geography no longer existed but became a stock-holding corporation. As compensation for their land, villagers were entitled to build homes on homestead plots (zhaijidi 宅基地), where they first built family homes, but then quickly demolished these homes to build tenements that they rented out to rural and urban migrants. Larger villages in peri-urban areas with transportation infrastructure such as Buji, Xixiang, Fuyong, and Shajing built village industrial parks that by the mid1990s had become key sites of labour-intensive manufacturing. ${ }^{15}$ Villagers called the resulting urban forms "new villages" (xincun 新村), while urban planners increasingly called them "villages inside the city" (chengzhongcun 城中村) (Na 2014). By the late 1990s, as Luohu-Shangbu gentrified and industrial manufacturing was pushed out of the downtown area, villagers in Nanshan, Yantian, and the outer districts increasingly crammed as many buildings as possible into their plots, resulting in tightly packed "handshake buildings" (woshoulou 握手樓). ${ }^{16}$ Shenzhen came to depend on these urban villages, which housed up to $50 \%$ of the population on only 4\% of the land (O'Donnell, Wong, and Bach 2017; Du 2020b). In the search for urban citizenship through acquiring a Shenzhen hukou, urban villages (particularly Luohu and Futian) became sites where migrants were sorted, especially in the first decades of the city: Those who were able to use the village as a launchpad into the locality became Shenzheners, while those who remained in the villages maintained their residual status (Bach 2010).

These early practices of reclaiming Bao'an created new forms of urban identity that re-deployed local status and status within the locality via the body. In the emerging social hierarchy of the new city, Shenzheners were those migrants who secured urban hukou through their jobs, while the original inhabitants were known as locals in the expanded sense of anyone indigenous to Bao'an County. In other words, the integration of Bao'an into Shenzhen produced a system in which individual status no longer derived from one's place of birth, but from one's place in the national bureaucracy. Well into the 1990s, an SEZ hukou could only be obtained through a transfer to bureaus and enterprises within the state apparatus. As the real estate industry developed, however, one purchased a Shenzhen hukou along with property within a prescribed area. After 2005 , as the city deindustrialised and expanded tertiary education opportunities, universities increasingly have served as places where outsiders secure Shenzhen hukou upon graduation.

Thus, to understand how Shenzhen constantly reclaims the new, we need to pay attention to a foundational paradox of the city as place: one inhabits the city through in situ "local" sites that lack legal status as such within the municipal apparatus. This contradiction is most clearly embodied by indigenous villagers, who received their hukou via traditional land holdings restructured as urban neighbourhoods within the municipal government, thus living on their historic lands without historic land rights. However, the contradiction between local claims and the authority of locality also reverberates in the city's intense debates about urban renewal, where differently localised Shenzheners compete to reclaim neighbourhoods that have been declared obsolete. Villagers, urban planners, and developers, as well as second generation Shenzheners and younger migrants have variously justified rights to reclaim neighbourhoods based on criteria such as place of birth, years of inhabitation, knowledge, sentiment, and local history. Expressed through the rhetoric of "belonging" (guishugan 歸屬感), these claims are based on the value of long-term inhabitation; living in a neighbourhood, sending a child to a neighbourhood school, and getting married in Shenzhen these everyday practices localise migrants, who come (like indigenous locals) to care for specific places. Nevertheless, in all cases of renewal, the city apparatus has retained final authority over these places, which do not exist for themselves, but rather as categories within the locality. The obsolescence of the local in Shenzhen and the state's authority to reclaim urban neighbourhoods through new localities does not derive from physical obsolescence, but from planning; a local neighbourhood becomes obsolete once a new municipal, provincial, or national plan comes into play. Implementing the plan on the ground may take a decade, during which the physical environment may prosper, even becoming a vibrant urban neighbourhood. But except in rare cases, once an area has been made obsolete to the locality, it can be physically reclaimed despite its

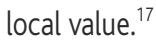

\section{Conclusion: The new local}

In recent years Shenzhen groups have formed to preserve Qing-era buildings in villages slated for demolition, and to capture the vibrancy of the urban villages in new planning. Moreover the city, recognising that administrative status is necessary but not sufficient to create a sense of belonging in the city, has announced plans to "revitalise" seven urban villages. ${ }^{18}$ These "new" forms of the Shenzhen local include makeovers to improve and modernise urban village infrastructure (e.g. Tianmian), demolition and replacement (e.g. Baishizhou), experimental urban planning (e.g. via the architecture firm Urbanus), selective historic preservation (e.g. Hubei), and assertions of identity through gates, temples, and museums (e.g. Xiasha) (see, inter alia, O'Donnell 2019; Mackinnon 2016). Perhaps because the villages, for decades now, have perched on the edge of vanishing, they appear more than ever as keepers of the city's connection to its multiple pasts and its diaspora populations. This is a central part of the cycle of producing obsolescence and redeploying its traces in order to create the new. "The vanishing," as Marilyn Ivy writes, "is never allowed to actually disappear, but is kept hovering... on the edge of absence" (Ivy 1995: 242-3). The always-but-not-quite vanishing villages contains within them both the anxious secrets of modernity's other, and the material for new forms of commodification and circulation in marketised economies.

Given the history outlined in this essay, one could say that contemporary Shenzheners (i.e. mostly white collar hukou-holding migrants) are now considered "local," the indigenous locals have been devalued to "guest status," and migrant workers are the city's new "boat dwellers" who cannot transfer their hukou to the city. However, unlike

15. Transportation infrastructure connecting these peri-urban areas to the SEZ were completed by the mid-1980s

16. So named because one can shake hands across the alley by leaning out the window.

17. James C. Scott (1999) addresses the tragic consequences of centralised governments pursuing well-intentioned, high modernist plans that do not take the local into account.

18. The seven urban villages are in Luohu (Wutong Al Ecological Town), Nanshan (Nantou Ancient City), Bao'an (Qingping Ancient Marketplace), Longhua (Guanlan Ancient Market), Longgang (Gankeng Hakka Town), and Dapeng New District (Dapeng Fortress and Nan'ao Market). See “深圳這7個城中村即將驚酆'蝶變'開啟'有機更新”探索” (Shenzhen zhe qi ge chengzhongcun jijiang jingyan "diebian" kaiqi "youji gengxin" tansuo, Seven Stunning Urban Villages), Shenzhen xinwen wang (深圳新聞網), 28 October 2019, http://www.sznews.com/news/ content/2019-10/28/content_22577398.htm (accessed on 21 April, 2020). 
status in Bao'an, which came with rights to the physical environment (even boat dwellers had recognised water rights), within the cultural geography of Shenzhen status and right of residence is ultimately defined with respect to changing administrative categories. Crudely speaking, as the state restructures, it calls into being new forms of locality, which in turn indigenise older settlements and concomitant residents, justifying the demolitions and rebuilding that have been associated with urbanisation in Shenzhen since "the first shot of reform and opening up." These localities, as such, can be adjusted without addressing "real world" issues such as resettlement, ecological health, and emotional belonging to a place.

Thus, in Shenzhen being "local" is increasingly a function of one's place in the national bureaucracy, rather than an inalienable connection to a historical place. Four decades since Shenzhen's founding, we see the city continuing its fabled expansion with new localities, for example technology giant Tencent's "Net City," to be completed by 2027, one of several major new town projects in the city, including Shenzhen Bay Headquarters City and the Qianhai Free Trade Zone, both built on reclaimed land. Arguably, these sites differ from Shenzhen's now classic localities such as Dongmen or Shangbu, which emerged out of Bao'an's cultural geographies. However, the declamatory logic of the new holds: When the pilot Shenzhen-Hong Kong Cooperative Zone of Qianhai was established in 2010, a (new) special zone was reclaimed from within the (old) special zone. Now, a full decade later, the outer districts have become the fastest developing areas in the city, and the Qianhai Cooperative Zone an important locality within the Greater Bay Area. Thus, even as Bao'an villages have been turned into localities with respect to Shenzhen City government, so too Shenzhen City, in the context of the GBA, has been turned into a locality with respect to Guangdong Province, making it available to be reclaimed - and hence made anew - by higher levels of government. Seen analytically, this is part of the cyclical production of obsolescence and renewal explored in this essay. Yet seen up close from the ground it has begun to raise questions about the limits of the performative logic of reclaiming the new: how sustainable is locality as a social form when success is based on the ongoing production of local obsolescence? In other words, how far can Shenzhen's locality stretch without breaking the communities and people who make it work?

I Mary Ann O'Donnell is an artist-ethnographer who has sought alternative ways of inhabiting Shenzhen through her blog, Shenzhen Noted, and the Handshake 302 public art project. She co-edited with Winnie Wong and Jonathan Bach Learning from Shenzhen: China's Post-Mao Experiment from Special Zone to Model City (2017) (mary. ann.odonnell@gmail.com).

I Jonathan Bach is Professor in the Global Studies Programme at The New School in New York, $725^{\text {th }}$ Ave, New York, NY 10011, USA. His recent work explores social change through the politics of memory, material culture, and urban space in Germany and China (bachj@ newschool.edu).

\section{References}

ANAGNOST, Ann. 1997. National Past-Times: Narrative, Representation, and Power in Modern China. Durham: Duke University Press.

BACH, Jonathan. 2010. "'They Come in Peasants and Leave Citizens': Urban Villages and the Making of Shenzhen, China." Cultural Anthropology 25(3): 421-58.

DU, Juan. 2020a. "Shenzhen's Urban Villages: A Micro-Political Tale from China's Mega-City." In Sascha DELZ, Rainer HEHL, and Patricia VENTURA (eds.), Housing the Co-op: A Micropolitical Manifesto. Berlin: Ruby Press. 165-76.

2020b. The Shenzhen Experiment: The Story of China's Instant City. Cambridge: Harvard University Press.

FAURE, David, and Helen SIU (eds.). 1995. Down to Earth: The Territorial Bond in South China. Stanford: Stanford University Press.

FU, Na. 2014. The Participatory Process of the Urban Village Redevelopment: Case Study in Shenzhen, China. Master's thesis. Texas: Community and Regional Planning, the University of Texas at Austin.

HASE, Patrick H. 1993. "Eastern Peace: Sha Tau Kok Market in 1925." Journal of the Hong Kong Branch of the Royal Asiatic Society 33: 147-202.

IVY, Marilyn. 1995. Discourses of the Vanishing: Modernity, Phantasm, Japan. Chicago: University of Chicago Press.

MACKINNON, Eli. 2016. "The Twilight of Shenzhen's Great Urban Village." Foreign Policy Online, 16 September 2016. https:// foreignpolicy.com/2016/09/16/china-demolition-economy-thetwilight-of-shenzhens-great-urban-village-baishizhou/ (accessed on 3 June 2020).

O'DONNELL, Mary Ann. 2019. "Heart of Shenzhen: The Movement to Preserve 'Ancient' Hubei Village." In Anastasia LOUKAITOUSIDERIS, and Tridib BANERJEE (eds.), The New Companion to Urban Design. London: Routledge. 480-93.

O'DONNELL, Mary Ann, and Yan WAN. 2016. "Shen Kong: Cui Bono." In Joshua BOLCHOVER, and Peter HASDELL (eds.), Border Ecologies: Hong Kong's Mainland Frontier. Basel: Birkhauser. 34-47.

O'DONNELL, Mary Ann, Winnie WONG, and Jonathan BACH (eds.). 2017. Learning from Shenzhen: China's Post-Mao Experiment from Experiment to Model City. Chicago: University of Chicago Press.

SCOTT, James C. 1999. Seeing Like a State: How Certain Schemes to Improve the Human Condition Have Failed. New Haven and London:Yale University Press. 